Journal of Bangladesh Academy of Sciences, Vol. 38, No. 1, 75-82, 2014

\title{
LEVELS OF REACTIVE NITROGEN IN SURFACE AND GROUND WATER SAMPLES OBTAINED FROM DIFFERENT PARTS OF BANGLADESH
}

\author{
M. ANOWAR K. PARVEZ, MAHFUZA MARZAN, SYEDA MORIAM LIZA AND \\ ZIA UDDIN AHMED*
}

Department of Microbiology, Jahangirnagar University, Savar, Bangladesh

\begin{abstract}
A total of 114 water samples collected from different parts of Bangladesh were analyzed for the level of reactive nitrogen species $\mathrm{NO}_{3}$ and $\mathrm{NH}_{3}$. Nitrate was determined in 20 surface water, 28 motorized deep tube well and 66 hand operated tube well samples. Ammonia was determined in 18 surface water, 14 deep tube well and 49 hand operated tube well samples. These sites were randomly selected. Nitrate levels were found to be generally low (below $3 \mathrm{mg} / \mathrm{l}$ ) in 112 of the 114 samples tested, which is much below permissible level of $10 \mathrm{mg} / \mathrm{l}$ of drinking water in Bangladesh. Ammonia concentration was, however, found to be about $4 \mathrm{mg} / \mathrm{l}$ in majority of the samples tested which is higher than maximum permissible limit of $0.5 \mathrm{mg} / \mathrm{l}$ in drinking water. Possible reasons for low level of nitrate and relatively high level of ammonia in surface and ground water samples in Bangladesh is discussed.
\end{abstract}

Key words: Reactive nitrogen, Nitrate and ammonia, Surface and ground water, Bangladesh

\section{INTRODUCTION}

$\mathrm{N}_{2}$ is abundant in air but it is chemically inert and as such cannot be part of natural biological nitrogen cycle on earth. $\mathrm{N}_{2}$ is split into nitrogen atoms that are then fixed through oxidation or reduction to produce several different reactive nitrogen species among which $\mathrm{NO}_{3}$ and $\mathrm{NH}_{3}$ are biologically important. Reactive nitrogen species in water and soil originate mainly from nitrogen chemically fixed during making fertilizer. Some soil microorganisms can also fix atmospheric nitrogen through complex enzymatic process. Throughout the 20th century anthropogenic use of nitrogen has been steadily increasing because of increased nitrogen fertilizer use in agriculture and burning of fossil fuel for energy production. Indeed human activity has added more nitrogen in earth's nitrogen cycle than nitrogen added through all other known natural processes combined (Fields 2004).

Use of chemically produced nitrogen fertilizer in Bangladesh is high in terms of use per unit area of arable land per year referred to here as use intensity. In fact this value appears to

\footnotetext{
* Corresponding author: <ahmedzu@yahoo.com>.
} 
be higher in Bangladesh compared to the neighbouring countries. In Bangladesh, human activity of a very large population living in extremely high density (which is the highest in the world for any nation state as opposed to city states), also significantly contributes to organic nitrogen replenishment of water and soil which may lead to high levels of reactive nitrogen species in soil and water. Limited data are available on the level of nitrate and ammonia in soil and water samples in Bangladesh (Azim et al. 2011). The present authors thought it of interest to undertake an exploratory study on the levels of $\mathrm{NO}_{3}$ and $\mathrm{NH}_{3}$ in samples of surface and ground water over a region of the country.

\section{MATERIALS AND METHODS}

A total of 114 water samples were collected in sterile plastic bottles (200 - $300 \mathrm{ml})$ from different parts of Bangladesh (mainly central Bangladesh and adjoining areas on the north and south). These samples included water from deep tube wells, hand operated shallow tube wells and closed inland water bodies such as ponds and lakes (Beels). Samples were analyzed within $24 \mathrm{hrs}$ after collection generally without the samples being refrigerated. It was difficult to ascertain the depth of the large number of tube wells used, but a rough guess can be made. Hand operated tube wells in Bangladesh usually occur at depth of around 45 meters and deep tube wells about 150 meters. Several parameters that are routinely analyzed in water sample analysis such as $\mathrm{pH}$, temperature, electrical conductivity (EC), total suspended solids (TSS), and biological oxygen demand (BoD) were determined for the samples. These have not been presented as they do not have significant direct relevance to the central focus of the study, which is providing an indication of $\mathrm{NO}_{3}$ and $\mathrm{NH}_{3}$ levels at random sites in a certain region of the country obviously avoiding sites dedicated to high level specific human activity. For general interest, however, the ranges found were: $\mathrm{pH} 5.2$ - 9.2, temperature 27.5 - 29.5, EC 0.66 - 10.98, TSS 1600 - $6800 \mathrm{mg} / \mathrm{l}$, BoD 0.08 - $1.3 \mathrm{mg} / \mathrm{l}$. It should be mentioned that extreme values were found only in a few cases.

Nitrate concentration in most of the water samples was determined by spectrophotometric method (APHA 1998) by measuring UV absorbance at $205 \mathrm{~nm}$ using a UV Specord 205 Analytic Jena spectrophotometer with quartz cells of $1 \mathrm{~cm}$ light path. A standard curve for nitrate concentration was prepared by dissolving $0.0722 \mathrm{~g} \mathrm{KNO}_{3}$ in $100 \mathrm{ml}$ nanopure water to make a stock solution containing $100 \mu \mathrm{g} / \mathrm{ml} \mathrm{NO}_{3}-\mathrm{N}$. Dilutions of this solution were made to contain various concentrations of nitrate and absorption was measured at $205 \mathrm{~nm}$. Absorption increased in a linear manner for up to $6 \mu \mathrm{g} / \mathrm{ml} \mathrm{NO}_{3}$ and this region of the curve was used to determine nitrate concentration of the experimental water samples. In some of the water samples nitrate determination was also carried out by steam distillation method (Bremner 1965). Nitrate levels in samples obtained from different sources were generally similar in both the methods used in the study. As such, the authors have pooled together the 
nitrate values obtained by these two methods and results presented in one Table. Ammonia concentration was determined by steam distillation method (Bremner 1965). Per cent recovery in steam distillation method was not experimentally determined but assume to be over $99 \%$. In the absence of correction for possible loss during processing the values may be regarded as representing the lower limits.

\section{RESULTS AND DISCUSSION}

Both in UV spectrophotometric determination of nitrate and determination of ammonia by steam distillation method appropriate recommended reagents were routinely used to minimize possible interference by contaminants present in water samples. The method of spectrophotometric determination of nitrate is based on the observation that nitrate shows strong UV absorption in the wavelength range of $190-210 \mathrm{~nm}$. The absorption spectrum of a solution of nitrate in distilled water containing sulfuric acid $(2.5 \mu$ l concentrated acid per ml of water) which was added to all experimental samples to prevent interference by hydroxide and carbonate that might be present in water samples is shown in Fig. 1A and that of a sample of distilled water containing $5 \mu \mathrm{g} / \mathrm{ml} \mathrm{KNO}_{3}$ in Fig. $1 \mathrm{~B}$. Distinct peak attributable to $\mathrm{NO}_{3}$ is clear in the wavelength range of $200-210 \mathrm{~nm}$ in Fig. 1B.
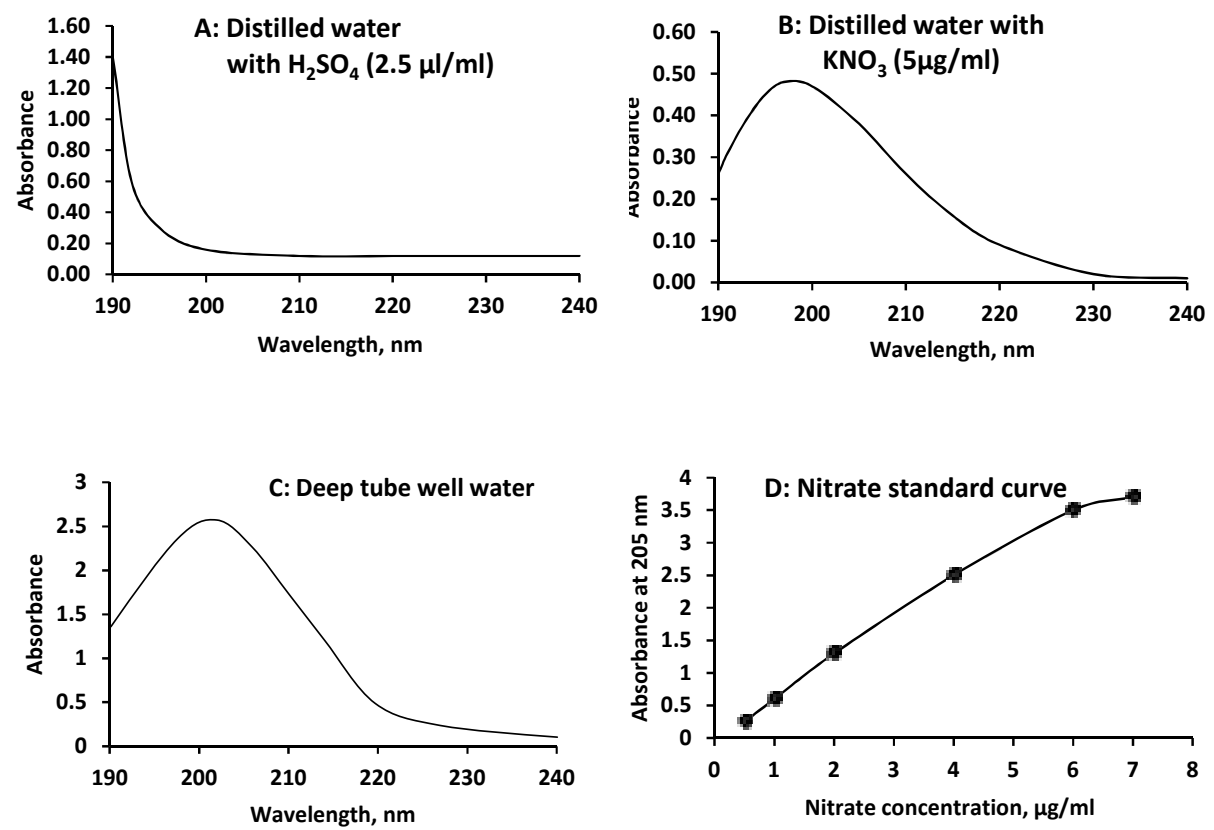

Fig. 1. Determination of nitrate in water samples by UV spectrophotometric method. (A) absorption curve of distilled water, (B) $\mathrm{KNO}_{3}$ solution, (C) deep tube well water, (D) standard concentration curve for nitrate determined by absorbance at $205 \mathrm{~nm}$ with solutions containing known quantities of $\mathrm{KNO}_{3}$. Figs $\mathrm{A}, \mathrm{B}$ and $\mathrm{C}$ are tracings drawn from computer printout of absorption spectrum over the wavelength range used, while in $\mathrm{D}$ independent absorption values were plotted to make the curve which was used to determine concentration of nitrate in experimental samples. 
Absorption spectrum of a sample of deep tube well water is shown in Fig. 1C where also the characteristic peak for nitrate is clear. Fig. 1D is a typical standard curve which was prepared by plotting absorbance at $205 \mathrm{~nm}$ of a series of $\mathrm{KNO}_{3}$ solutions containing known quantities of $\mathrm{NO}_{3}$. A linear absorption curve was obtained for nitrate concentration in the range of $0.5-6.0 \mu \mathrm{g} / \mathrm{ml}$ in distilled water. This region of the curve was used to determine nitrate concentration in unknown samples after appropriate dilution of high nitrate containing samples as necessary.

Results on the levels of nitrate in different water samples are presented in Table 1. Total number of different water samples analyzed was: surface water 20, deep tube well 28 and shallow hand operated tube well 66. Since the nitrate ammonia values were distributed in a rather broad range, these have been presented for brevity in several concentration range groups.

Table 1. Nitrate concentration in different water samples determined by UV spectrophotometric and/or by steam distillation methods.

\begin{tabular}{lccc}
\hline \multirow{2}{*}{$\begin{array}{c}\text { Nitrate concentration } \\
(\mathrm{mg} / \mathrm{l})\end{array}$} & \multicolumn{3}{c}{$\begin{array}{c}\text { Sample source and number of in different nitrate } \\
\text { concentration ranges }\end{array}$} \\
\cline { 2 - 4 } & $\begin{array}{c}\text { Surface water } \\
\mathrm{n}=20\end{array}$ & $\begin{array}{c}\text { Deep tube well } \\
\mathrm{n}=28\end{array}$ & $\begin{array}{c}\text { Hand tube well } \\
\mathrm{n}=66\end{array}$ \\
\hline $0-1.0$ & 11 & 12 & 38 \\
$1.1-2.0$ & 2 & 10 & 8 \\
$2.1-3.0$ & 4 & 8 & 17 \\
$3.1-4.0$ & 1 & 0 & 3 \\
$4.1-5.0$ & 1 & 0 & 3 \\
$5.1-6.0$ & 0 & 0 & 0 \\
$6.1-7.0$ & 1 & 0 & 1 \\
$7.1-8.0$ & 0 & 0 & 1 \\
$8.1-9.0$ & 0 & 0 & 0 \\
$9.1-10.0$ & 0 & 0 & 0 \\
$10.1-11.0$ & 0 & 0 & 0 \\
$11.1-12.0$ & 0 & 0 & 2 \\
& 0 & 0 & \\
More than 12.0 & & & (one sample with 21 mg/l and \\
& & & another with 70 mg/l)* \\
\hline
\end{tabular}

Total number of samples: 114 . *These relatively high values could be related to the presence of untreated sewage ponds or effluent discharged from nearby industrial units.

Some of the water samples were analyzed for determination of ammonia by steam distillation method at a facility at the Bangladesh Institute of Nuclear Agriculture in Mymensingh. The values are similarly presented in Table 2 in concentration range groups. 
Nitrate is potentially hazardous to human health. This reactive entity can be reduced in vivo and in food to nitrite that can readily react with other nitrostable compounds present in food to produce harmful $N$-nitrosocompounds. The serious illness methaemoglobinaemia (blue baby syndrome) which causes failure of red blood cells to carry oxygen in different parts of the body is caused by excess nitrate in drinking water. Generally, daily nitrate intake of $3.7 \mathrm{mg} / \mathrm{kg}$ of body weight is permissible. The permissible level of nitrate in drinking water in Bangladesh is $10 \mathrm{mg} / \mathrm{l}$.

Table 2. Ammonia concentration in different water samples determined by steam distillation method.

\begin{tabular}{lccc}
\hline \multirow{2}{*}{$\begin{array}{c}\text { Ammonia concentration } \\
(\mathrm{mg} / \mathrm{l})\end{array}$} & \multicolumn{3}{c}{$\begin{array}{c}\text { Sample source and number in different } \\
\text { ammonia concentration ranges }\end{array}$} \\
\cline { 2 - 4 } & $\begin{array}{c}\text { Surface water } \\
\mathrm{n}=18\end{array}$ & $\begin{array}{c}\text { Deep tube well } \\
\mathrm{n}=14\end{array}$ & $\begin{array}{c}\text { Hand tube well } \\
\mathrm{n}=49\end{array}$ \\
\hline $0-1.0$ & 5 & 5 & 7 \\
$1.1-2.0$ & 4 & 4 & 8 \\
$2.1-3.0$ & 6 & 4 & 23 \\
$3.1-4.0$ & 1 & 1 & 4 \\
$4.1-5.0$ & 1 & 2 & 4 \\
$5.1-6.0$ & 0 & 0 & 1 \\
$6.1-7.0$ & 1 & 0 & 0 \\
$7.1-8.0$ & 0 & 0 & 0 \\
$8.1-9.0$ & 0 & 0 & 0 \\
$9.1-10.0$ & 0 & 0 & 0 \\
\hline
\end{tabular}

Total number of samples: 81 .

The level of reactive nitrogen species such as nitrate and ammonia in soil and water in a particular geographic region is influenced by several processes such as biologically fixed atmospheric nitrogen by legume cultivation, addition of chemically fixed nitrogen in the form of inorganic fertilizer and high level vegetation and microbial growth that is favoured by a mild climate and a large population in high density. This situation is typically exemplified by conditions prevailing in Bangladesh.

Bangladesh with a very large population (now estimated to be about 160 million) and high population density (about 1100 persons per square kilometer) presents a unique biological scenario (Ahmed 2002). Mild climate, extensive use of fertilizer in agriculture and farming, activity of a very large human population living in extremely high density and poor waste and sewage disposal system are among the major factors that significantly influence the biological nitrogen cycle. Limited data are available on the level of nitrate and ammonia in water samples in areas near landfill sites in Bangladesh (Azim et al. 2011). In this study, in the two ponds that were analyzed nitrate concentrations were 8.4 and $5.6 \mathrm{mg} / \mathrm{l}$ and ammonia 15.4 and $23.8 \mathrm{mg} / \mathrm{l}$. In ground water obtained from two deep tube wells and two hand operated tube wells located in areas surrounding the landfill site nitrate concentration was generally similar and below national acceptable limit, but 
ammonia concentration was much above (more than 100 times) the acceptable limit of $0.5 \mathrm{mg} / \mathrm{l}$. Low nitrate levels (4 $\mathrm{mg} / \mathrm{l}$ or less) were also reported in surface and underground water samples in several other areas of Bangladesh, such as Chapai Nawabganj, Faridpur, Laksmipur and Comilla (BGS and DPHE 2001, Rasul and Jahan 2010, Ahmed et al. 2010).

Annual total use of nitrogen fertilizer in Bangladesh is relatively low because of small land area, but use per unit land area per year (use intensity) is quite high in Bangladesh, much higher than the neighbouring countries. Total arable land of a country and quantity of annual fertilizer use can give an estimate of fertilizer use intensity. In Bangladesh total arable land is estimated to be approximately 7.2 million hectares (Karim 2002). Information on the quantity of nitrogen fertilizer use, however, is not readily available. A tentative reported value (Ahmed 2011) indicates that 1.8 million metric tons (MT) of urea was imported in Bangladesh in 2011, which may be typical urea import per year in recent years. Annual fertilizer production (most of this is probably urea) in Bangladesh in 2008 is stated to be approximately 1.5 million MT (Statistical Pocket Book of Bangladesh 2009). Using these values it is calculated that 0.45 ton of chemical fertilizer used in Bangladesh per hectare per year. The corresponding values for other countries (obtained from Internet sources) in this region are: Thailand 0.11 ton per hectare per year, India 0.12 ton, Indonesia 0.15 ton, Malaysia 0.15 ton, and Pakistan 0.26 ton.

The levels of nitrate present in water samples analyzed in the present study are generally low. Data available for several other Asian countries indicate higher levels of nitrate in ground water samples (IARC Monograph Vol. 94). These high values could be the consequence of extensive use of nitrogen fertilizer and relative scarcity of vegetation in the areas studied due to dry and hot climatic conditions, that is, lack of an active biotic cycle. In mild humid climate conversely, high nitrogen input would trigger a highly active biological cycle that would keep nitrate actively cycling thereby preventing free nitrate accumulation. In the present study the low level of nitrate that have been observed in most samples could be related to a highly active nitrogen cycle in operation which is favoured by mild climate and high level anthropogenic input of nitrogen.

Ammonia concentration in most of the samples analyzed was less than $5 \mathrm{mg} / \mathrm{l}$, which is higher than the permissible level $1.5 \mathrm{mg} / \mathrm{l}$. Relatively high level of ammonia in surface water is perhaps related to discharge of human and animal waste that originates from the activity of a large high density human population living in areas surrounding the water body and occurrence of low levels of ammonia metabolizing microbes. Ammonia is less reactive than nitrate but it is not regarded as a major health hazard to humans although its presence may impart disagreeable odor to drinking water. 
Results of the study indicate that in Bangladesh, despite high nitrogen deposition in soil in the form of fertilizer, the level of nitrate in surface water is relatively low. The amount of fertilizer added to agricultural land is high which may produce higher levels of $\mathrm{N}_{2} \mathrm{O}$ (a green house gas) by the action of denitrifying bacteria. However, drainage of our surface water bodies from surrounding areas of human habitation is also very high which carries both inorganic and organic nitrogen, the latter might account for relatively high ammonia level in samples analyzed. It is possible that despite high intensity nitrogen deposition in Bangladesh, accumulation of high level reactive nitrogen species in soil and water is unlikely to be high in the near future due to a highly active cycle of eutrophication and biomass production. Thus, in Bangladesh high level accumulation of reactive nitrogen species in land and water may not be a limiting factor in fertilizer use. More extensive studies on these issues would be of considerable scientific interest.

The abundance and biology of the microorganisms associated with a highly active nitrogen cycle has not been systematically investigated. Preliminary observations (results not shown) suggest that surface water in Bangladesh which is generally of high trophic level can potentially carry high load of nitrogen metabolizing bacteria including bacteria that can grow in vitro at high levels of exogenous nitrate (nitrate tolerant bacteria). Contributions of associated bacterial population in maintaining reactive nitrogen balance in water and soil may be a subject of both academic interest and of potential practical value.

\section{ACKNOWLEDGEMENT}

The authors express their sincere thanks to authorities of Wazed Miah Science Research Centre, Jahangirnagar University for access to the UV Specord 205 Analytic Jena spectrophotometer, and to Bangladesh Institute of Nuclear Agriculture at Mymensingh for providing steam distillation facilities for ammonia and nitrate determination.

\section{REFERENCES}

Ahmed, M.J., M.R. Haque and T.M.A. Haque. 2010. Physicochemical assessment of surface and ground water resources of greater Comilla region of Bangladesh. Int. J. Chem Sci Tech. 1: 48-55.

Ahmed, Z. U. 2002. Biomedical Research in Bangladesh: Silent frontiers of opportunity. J. Asiatic. Soc. Bangladesh, Sci. Golden Jubilee Issue 28: 63-80.

APHA. (American Public Health Association). 1998. $\mathrm{NO}_{3}{ }^{-}$: Ultraviolet spectrophotometric screening method. Standard methods for the examination of water and wastewater. $20^{\text {th }}$ Edition. Water Pollution Control Federation. Washington DC. Vol. 1, p. 4-115.

Azim, M., M.M. Rahman, Riaz H. Khan and A.T.M. M. Kamal. 2011. Chracteristics of leachate generated at landfill sites and probable risks of surface and groundwater pollution in the surrounding areas: A case study of Mutuail landfill site, Dhaka. J. Bangladesh Acad. Sci. 35: 153-160. 
BGS (Bangladesh Geological Survey) and DPHE (Directorate of Public Health Engineering). 2001-Report.

Bremner, J.M. 1965. Inorganic Forms of Nitrogen. In: Methods of Soil Analysis. Part 2. Chemical and Microbiological Properties. American Society of Agronomy Monograph No. 9. Black C.A.. (Ed). Madison, Wisconsin. USA. 1965. pp. 13-14.

Fields, S. 2004. Global nitrogen: cycling out of control. Environ. Health Perspect. 112: A556A563.

IARC 2010 - International Agency for Research on Cancer. World Health Organization. Ingested nitrate and nitrite and cyanobacterial peptide toxins. Monograph 94.

Karim, Zahurul. 2002. Progress of agricultural development in Bangladesh. In: Bangladesh Vision 2021. Proc. the National Symposium on Science and Technology. Bangladesh Academy of Sciences. pp. 83-110.

Rasul, M.T. and M.S. Jahan. 2010. Quality of ground and surface water of Rajshahi city area for sustainable drinking water source. J. Sci. Res. 2: 577-584.

Statistical Pocket Book of Bangladesh. 2009. Bangladesh Bureau of Statistics. Production of Selected Industrial Items. p. 227.

(Received revised manuscript on 8 April, 2014) 